\title{
DISAPPEARANCE RATE OF CONCENTRATED PROCONVERTIN EXTRACTS IN CONGENITAL AND ACQUIRED HYPOPROCONVERTINEMIA *
}

\author{
By M. SIlviJA HOAG, PAUL M. AGGELER and ALFRED H. FOWELL
}

\author{
(From the Hematology Research Laboratory, Children's Hospital, San Francisco, and the \\ Chemical Research Laboratory, Cutter Laboratories, Berkeley, Calif.)
}

(Submitted for publication July 6, 1959; accepted November 12, 1959)

While developing methods for extraction and concentration of various adsorbable blood clotting factors (1-3), we found that an extract made by $\mathrm{Al}(\mathrm{OH})_{3}$ adsorption of citrated plasma contained large amounts of proconvertin and only small quantities of prothrombin, Stuart factor (4), and plasma thromboplastin component (PTC) (5). The present report is concerned with the disappearance rate of proconvertin following the rapid intravenous administration of this extract to nine patients with congenital or acquired hypoproconvertinemia.

In their original description of congenital proconvertin ${ }^{1}$ deficiency, Alexander, Goldstein, Landwehr and Cook (6) indicated that the corrective effect of normal plasma or serum transfusion was lost within 24 hours. After transfusion of whole blood to an infant with severe congenital hypoproconvertinemia, Hitzig and Zollinger (7) found the proconvertin half-life to be 115 to 135 minutes. The half-life was 57 minutes following injection of $20 \mathrm{ml}$ of an extract having a proconvertin potency 30 times that of normal plasma.

Frick (8) stated that the half-life of proconvertin was 5.5 to 6 hours following plasma transfusion in normal subjects made hypoproconvertinemic by the intravenous administration of Warfarin sodium. ${ }^{2}$ Didisheim, Loeb, Blatrix and Soulier (9) stated that the half-life of proconvertin was 50 to 55 hours, following intravenous admin-

* This work was supported by United States Public Health Service grant no. H-2754 and by a grant from the Girls' Recreation Club of San Francisco.

1 Serum prothrombin conversion accelerator (S.P.C.A.), Factor VII, stable factor (SF), stable prothrombin conversion factor, co-thromboplastin.

2 Warfarin is 3-( $\alpha$-acetonyl benzyl)-4-hydroxy-coumadin. The sodium salt is produced under the name of Coumadin Sodium by Endo Products Inc., Richmond Hill, N. Y. istration of a concentrated proconvertin extract to one patient with cirrhosis of the liver.

All previous investigators have been able to demonstrate exponential disappearance curves with only a single component. We have repeatedly found exponential curves with two components in all experiments except that performed on the normal subject. Both the net rise in proconvertin in the blood and the disappearance rate following injection of the extract were dependent on the degree of deficiency in the recipient.

\section{METHODS}

All blood was drawn in uncoated glass syringes, immediately mixed with $1 / 10$ volume of 3.2 per cent sodium citrate in 0.7 per cent $\mathrm{NaCl}$ and centrifuged at $2,000 \mathrm{rpm}$ for 20 minutes. The plasma was removed and stored in stoppered glass tubes at $-20^{\circ} \mathrm{C}$.

Proconvertin. This was measured by a modification of the method of Owren and Aas (10), using plasma from two patients ( $\mathrm{Bi}$. C. and Bo. C.) with severe congenital proconvertin deficiency as substrate. These patients had normal prothrombin consumption and thromboplastin generation tests and normal concentrations of Stuart factor. Almost identical results were obtained using partially adsorbed beef plasma as substrate in tests on patients having normal Stuart factor concentrations. The proconvertin time was determined after the addition of $0.1 \mathrm{ml} 0.025 \mathrm{M} \mathrm{CaCl}_{2}$ to a mixture of 0.1 $\mathrm{ml}$ of substrate plasma, $0.1 \mathrm{ml}$ rabbit brain thromboplastin, and $0.1 \mathrm{ml}$ of the patients' plasma (1/10 dilution in 0.85 per cent $\mathrm{NaCl}$ ). Duplicate tests were done on each sample and the times averaged. The proconvertin concentration was determined by referring to a standardization curve which was constructed separately for each new lot of reagents. All tests in any given experiment were performed on the same day with the same reagents. The standardization curve was constructed by plotting the proconvertin time against the plasma dilution on log$\log$ paper using $1 / 10$ to $1 / 200$ dilutions of normal plasma. The results obtained in 5 to 7 normal subjects were averaged. Our normal value for this test is 100 per cent $(2 \mathrm{SD}= \pm 25$ per cent $)$. Deficiencies were arbitrarily classified as being mild with values between 50 and 75 
per cent, moderate between 20 and 49 per cent and severe between 0 and 19 per cent.

Prothrombin complex and Stuart factor. Prothrombin complex activity was measured by the method of Quick (11) using dehydrated rabbit brain as the source of tissue thromboplastin. Prothrombin and Stuart factor were measured by the method of Hjort, Rapaport and Owren (12). Stuart factor was measured by the method of Bachmann, Duckert and Koller (13), which is similar to the method of Sise, Lavelle and Becker (14) except that optimum concentrations of cephalin and Russell viper venom are determined.

Preparation of extract. Citrated (ACD) blood bank plasma, from 1 to 26 days old, was stored in the frozen state until sufficient quantity had been accumulated for extraction ( 3 to 4 months). ${ }^{3}$ The plasma was thawed at $37^{\circ} \mathrm{C}$ to a final temperature of $25^{\circ} \mathrm{C}$ and mixed with $\mathrm{Al}(\mathrm{OH})_{3}$ (assayed as 2.4 per cent $\mathrm{Al}_{2} \mathrm{O}_{3}$ in water at neutral $\mathrm{pH}$ ) in $1 / 75$ of the original plasma volume for 30 minutes. After centrifugation the $\mathrm{Al}(\mathrm{OH})_{3}$ sediment was washed with 0.9 per cent $\mathrm{NaCl}$ in $3 / 4$ of the original plasma volume for 30 minutes at $25^{\circ} \mathrm{C}$ and centrifuged. The washed sediment was eluted with 0.08 $\mathrm{M} \mathrm{Na} \mathrm{NaPO}_{4}$ solution, adjusted to $\mathrm{pH} 8.0$ in $1 / 4$ of the original plasma volume, stirred for 30 minutes at $25^{\circ} \mathrm{C}$ and centrifuged. The supernatant was decanted and brought to $\mathrm{pH} 5.6$ in a concentration of 40 per cent ethanol at $-5^{\circ} \mathrm{C}$, suspended in cold water and freezedried. The dried precipitate was dissolved in $1 / 100$ original plasma volume of Plasmanate, ${ }^{4}$ sterile filtered and stored in the frozen state or lyophilized. The material was tested in rats and rabbits for toxicity and pyrogenicity before use in human subjects.

\section{RESULTS}

\section{Clotting factor content}

Three lots of extract prepared from 25 to 100 $\mathrm{L}$ pools of plasma were used. The content of clotting factors as compared with normal plasma was: proconvertin, 35 to 88 times; prothrombin plus Stuart factor, 6 to 30 times; Stuart factor, 3.6 to 8.6 times; proaccelerin, antihemophilic factor and thrombin absent; and PTC negligible.

\section{Stability}

The lyophilized extracts were stable when tested at 18 months, the reconstituted frozen ex-

\footnotetext{
${ }^{3} \mathrm{We}$ are indebted to the Irwin Memorial Blood Bank of the San Francisco Medical Society for its cooperation in collecting these plasmas.

4 Produced by the Cutter Laboratories, Berkeley, Calif. The product is made from the effluent of Cohn fraction IV-1 and contains approximately 88 per cent albumin, the remainder being $\alpha$ - and $\beta$-globulins. It is heated for 10 hours at $60^{\circ} \mathrm{C}$ to destroy the virus of homologous serum jaundice.
}

tract at 17 months, and the reconstituted liquid extract after storage at room temperature for 48 hours. The proconvertin potency of the extract was not diminished after incubation with the plasma of a patient with severe congenital hypoproconvertinemia for 140 minutes at $37^{\circ} \mathrm{C}$.

\section{Administration}

Sixteen studies were made on one moderately deficient and four severely deficient patients with congenital hypoproconvertinemia, two patients with mild deficiency of proconvertin of unknown etiology, one patient with severe hepatitis, one normal subject and the same subject made hypoproconvertinemic by the oral administration of Warfarin. A summary of the results is given in Table I. In these experiments 14 to $58.5 \mathrm{ml}$ of extract was given intravenously within three to seven minutes. Because of the small volumes employed no correction for plasma volume expansion was made. The plasma volume was not measured and an average value of $45 \mathrm{ml}$ per $\mathrm{kg}$ was used in calculating the predicted net rise in proconvertin at $\mathrm{T}=0$ (time of completion of injection). For purposes of these experiments one unit of proconvertin is defined as the amount in $1 \mathrm{ml}$ of normal human plasma.

\section{Urine recovery experiments}

In several experiments no proconvertin could be recovered in the urine collected during the period following injections of the extract when 90 per cent of the proconvertin activity disappeared from the blood. The volume of urine collected during this time was only 10 per cent of the plasma volume so that if any proconvertin was present it should have been easily detected. This does not prove, however, that proconvertin was not lost through the kidney and subsequently inactivated.

\section{Reactions}

Except for transient flushing of the face in two patients during the injection there were no subjective reactions during or following the use of these extracts. The temperature, pulse and respiration remained unchanged. The normal subject, a physician, subsequently developed acute hepatitis at a time consistent with the incubation period of homologous serum jaundice. However, 
M. SilviJA HOAG, PAUL M. AGGELER AND ALFRED H. FOWELL

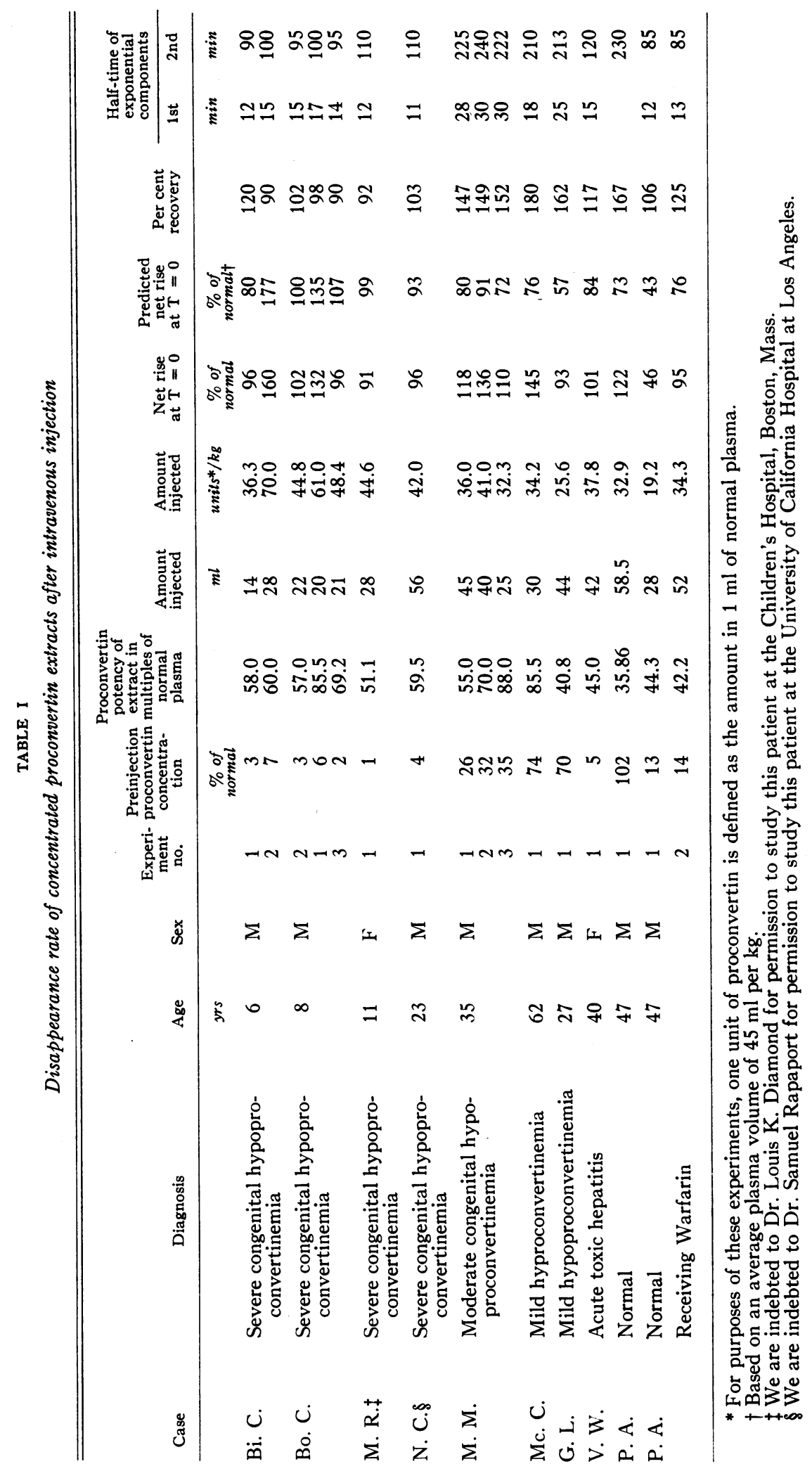




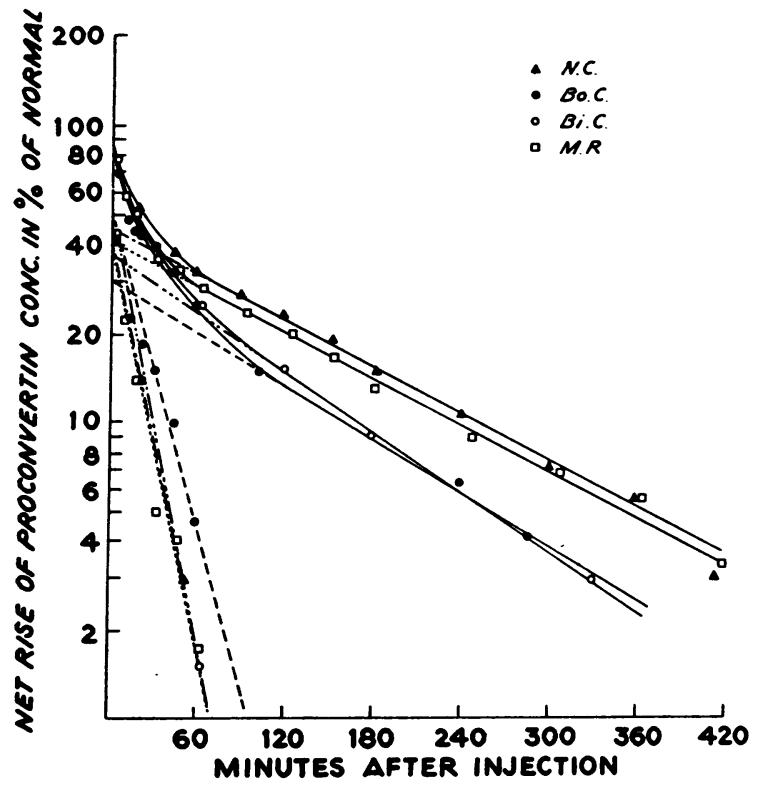

Fig. 1. Disappearance curves following injection OF CONCENTRATED PROCONVERTIN EXTRACT IN FOUR PATIENTS WITH SEVERE CONGENITAL HYPOPROCONVERTINEMIA. (N. C., $42.0 \mathrm{U}$ per kg ; Bo. C., $48.4 \mathrm{U}$ per kg ; Bi. C., 36.3 U per kg; M. R., 44.6 U per kg.)

at the time he received the extracts, he was also exposed to several cases of infectious hepatitis. None of the other five patients who received the same lot of extract, nor those receiving other lots, developed any late sequelae.

\section{Analysis of disappearance curves.}

Disappearance curves having two exponential components were obtained in all experiments except the one in the normal subject. The net rise in proconvertin at $\mathrm{T}=0$ was obtained by extrapolation of the exponentials. The two exponential components (net rise of proconvertin concentration $=\mathrm{Ae}^{-\mathrm{k}_{1} \mathrm{t}}+\mathrm{Be}^{-\mathrm{k}_{2} \mathrm{t}}$ ) were determined graphically by subtraction of the extrapolated final slope $\left(\mathrm{Be}^{-\mathrm{k}_{2} \mathrm{t}}\right)$ from the initial portion of the curve; $\mathrm{Ae}^{-\mathrm{k}_{1} t}$ was plotted in this way. The net rise in proconvertin at $\mathrm{T}=0$ is equal to the sum of the extrapolated exponential component intercepts $(\mathrm{A}+\mathrm{B})(15)$.

A. Severe congenital hypoproconvertinemia. In Figure 1 are shown the results of a single experiment in each of four patients with severe congenital hypoproconvertinemia (N. C., M. R., Bo. C. no. 3 and Bi. C. no. 1). The results of three ex- periments done on one of these patients (Bo. C.) are shown in Figure 2. The similarity of the slopes of the disappearance curves is apparent. In seven experiments done on these four patients, the half-time of the first exponential component of the disappearance curve varied from 11 to 17 minutes and that of the second from 90 to 110 minutes. The dose of proconvertin varied from 36.3 to 70 units per $\mathrm{kg}$. Within this range the slope of the disappearance curve did not appear to be dose dependent. The net rise in proconvertin in the patient's blood at $\mathrm{T}=0$ was 91 to 160 per cent; the predicted net rise was 80 to 177 per cent. The net recovery averaged 99 per cent of the predicted value.

B. Moderate congenital hypoproconvertinemia. In one patient (M. M.) with moderate congenital hypoproconvertinemia considerably slower disappearance rates were found than in patients with the severe form of the disease. In Figure 3 one experiment on this patient (M. M. no. 3) is compared with a similar experiment on a patient (Bo. C. no. 2) with severe congenital hypopro-

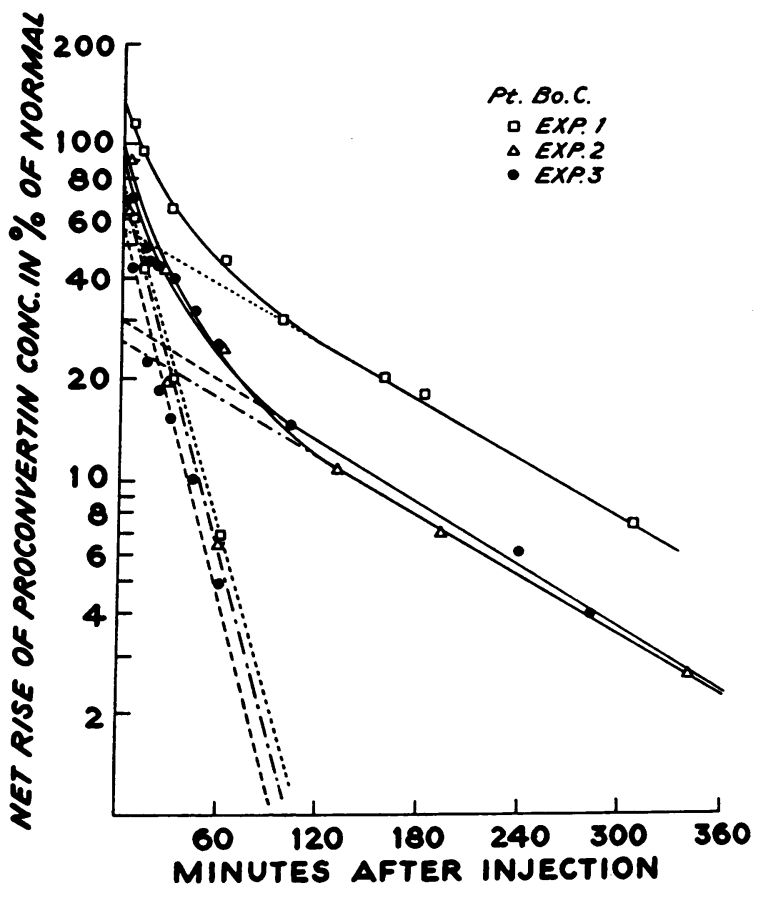

Fig. 2. Disappearance curves following injection OF CONCENTRATED PROCONVERTIN EXTRACT ON THREE OCCASIONS TO ONE PATIENT WITH SEVERE CONGENITAL HYPOproconvertinemia. (Bo. C.: Exp. no. 1, $61.0 \mathrm{U}$ per kg; Exp. no. 2, $44.8 \mathrm{U}$ per kg; Exp. no. 3, $48.4 \mathrm{U}$ per kg.) 


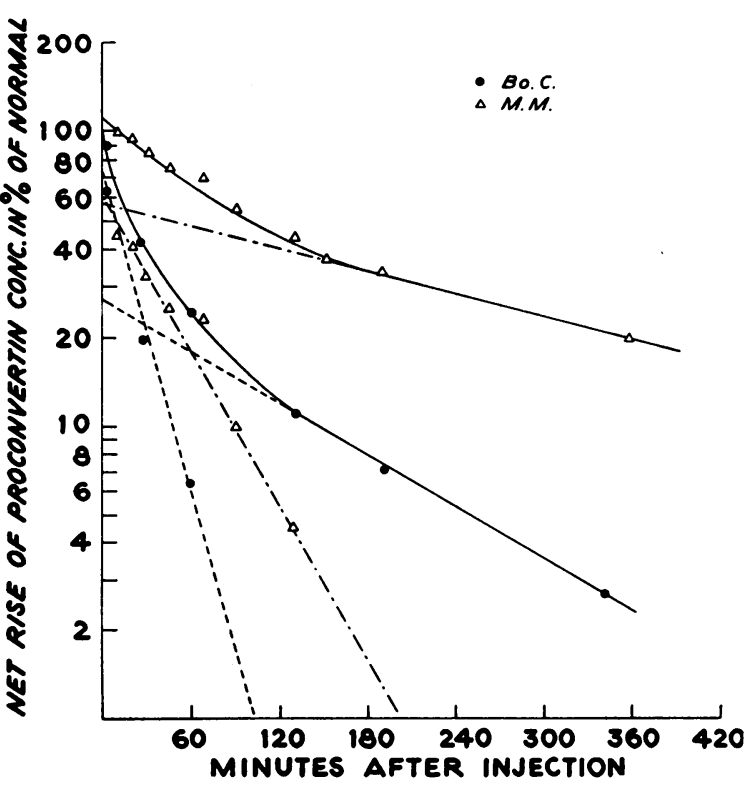

Fig. 3. Disappearance CURVES Following injection OF CONCENTRATED PROCONVERTIN EXTRACT TO ONE PATIENT WITh SEVERE (Bo. C., 44.8 U PER KG) AND ONE WITH MODERATE (M. M., 32.3 U PER KG) CONGENITAL HYPOPROCONVERTINEMIA.

convertinemia. Following doses of 32.3 to 41 units per $\mathrm{kg}$, the half-time of the first exponential component of the disappearance curve was 28 to 30 minutes and that of the second 222 to 240 minutes. The net rise in proconvertin in the patient's blood at $\mathrm{T}=0$ was 110 to 136 per cent. The net recovery was 147 to 152 per cent of the predicted value.

C. Mild hypoproconvertinemia. Two patients with mild fluctuating hypoproconvertinemia were studied. One, Mc. C., is the maternal grandfather of Bi. C. and Bo. C. He had no history of abnormal bleeding. At various times his proconvertin concentration had been found to be between 54 and 70 per cent. The other patient, G. L., had a mild bleeding tendency, his most recent episode having been prolonged bleeding following hemorrhoidectomy. His proconvertin concentration had varied between 18 and 74 per cent. The results of the experiments in these patients, done when their proconvertin concentrations were 70 and 74 per cent, were in most respects similar to those in the patient with moderate congenital hypoproconvertinemia. The half-time of the first exponential component of the disappearance curve was 18 and 21 minutes while that of the second was 210 minutes in both cases. Following doses of
25.6 and 34.2 units per $\mathrm{kg}$ the net rise in proconvertin in the patient's blood at $\mathrm{T}=0$ was 93 and 145 per cent, which amounted to 162 and 180 per cent of the predicted value.

$D$. Liver disease. The results of one experiment performed in a patient with acute hepatitis with a proconvertin concentration of 5 per cent were similar to those obtained in the patients with severe congenital hypoproconvertinemia. The half-time of the first exponential component was 15 minutes and that of the second 120 minutes. Following a dose of 37.8 units per $\mathrm{kg}$, the net rise of proconvertin in the patient's blood at $\mathrm{T}=0$ was 101 per cent which amounted to 117 per cent of the predicted value.

E. Normal subject before and after Warfarin. One normal subject was studied before and after the oral administration of Warfarin. The disappearance curves following administration of the extract are shown in Figure 4. Before Warfarin a disappearance curve was obtained with a single exponential component, with a half-time of 230 minutes. The net rise of 122 per cent in proconvertin at $\mathrm{T}=0$ in the patient's blood, after injection of 32.9 units per $\mathrm{kg}$, was 167 per cent of the predicted value.

Over a period of 12 days he was given orally

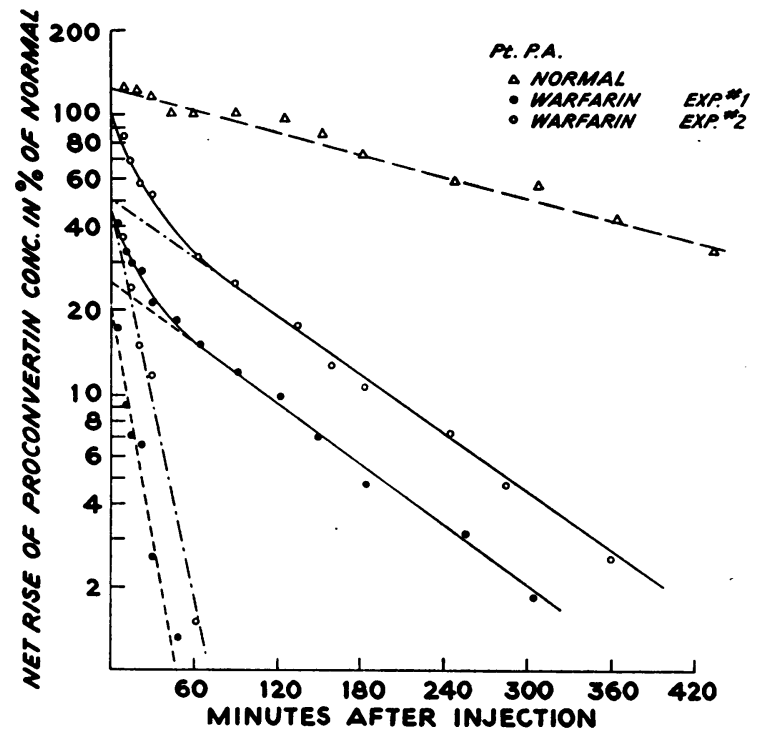

Fig. 4. Disappearance curves following INJeCtion OF CONCENTRATED PROCONVERTIN EXTRACT TO A NORMAL SUBJECT BEFORE AND AFTER THE ADMINISTRATION OF WARFARIX. (Normal, before, $32.9 \mathrm{U}$ per kg ; after Warfarin, Exp. no. 1, 19.2 U per kg; after Warfarin, Exp. no. 2, $34.3 \mathrm{U}$ per kg.) 
$12.5 \mathrm{mg}$ Warfarin daily until his proconvertin level had become stabilized. This dose was continued throughout the period of the experiments. During the five days preceeding the first experiment his proconvertin concentration varied between 9 and 13 per cent, and the Quick test and the Stuart factor concentrations varied between 18 and 22 per cent. In the first experiment he was given a dose of extract sufficient to produce a net rise of 46 per cent in the proconvertin concentration of his blood at $T=0$. Two days later he was given approximately twice this dose which resulted in a net rise of 96 per cent at $\mathrm{T}=0$. The net recoveries were 106 and 125 per cent of the predicted values.

The slopes of the disappearance curves were almost identical in the two experiments, the halftime being 12 and 13 minutes for the first component and 85 minutes for the second. These results are similar to those found in severe congenital hypoproconvertinemia and are in striking contrast to those obtained in the same subject befor the administration of Warfarin.

\section{Effect of extracts on other clotting tests}

The effect of the extracts on clotting factors other than proconvertin was studied in several patients. Three of the patients with untreated

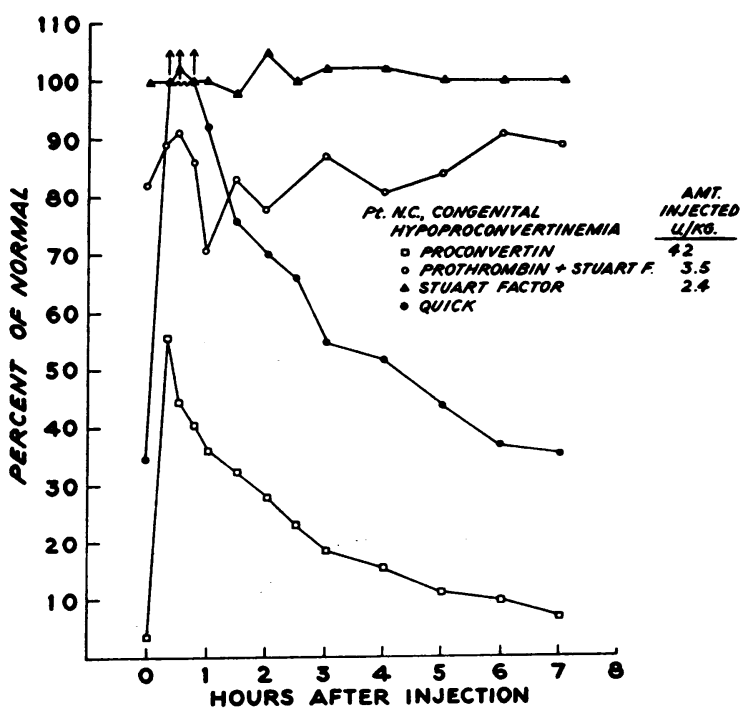

Fig. 5. THE EFFeCt OF THE AdMINISTRATION OF A CONCENTRATED PROCONVERTIN EXTRACT ON THE QUICK, PROCONVERTIN, PROTHROMBIN AND STUART FACTOR TESTS IN A PATIENT WITH SEVERE CONGENITAL HYPOPROCONVERTINEMIA.

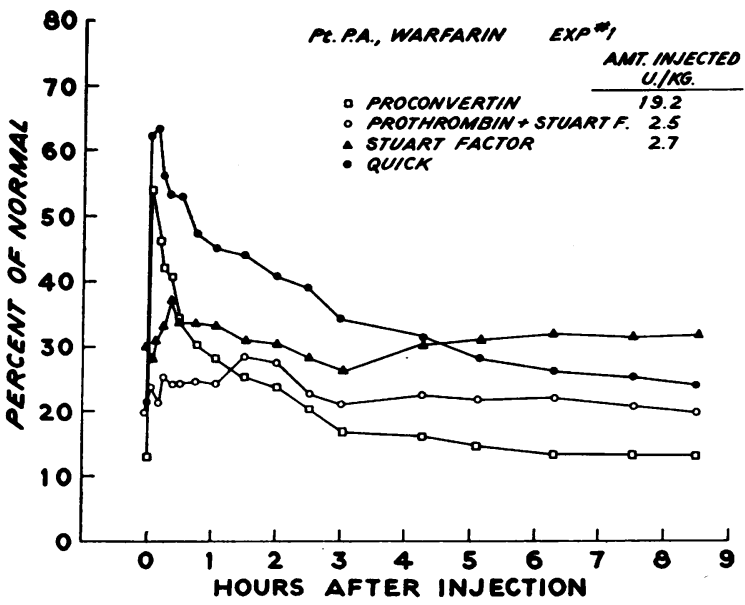

Fig. 6. THE EFFECT OF THE ADMINISTRATION OF A CONCENTRATED PROCONVERTIN EXTRACT (19.2 U PER KG) ON THE QUick, PROCONVERTIN, PROTHROMbin AND StUART FACTOR TESTS IN A NORMAL SUBJECT RECEIVING WARFARIN.

severe congenital deficiencies (Bi. C., Bo. C. and M. R.) with proconvertin concentrations of 1 to 7 per cent had Quick test values of 9 to 12.5 per cent. One patient (N. C.) showed a greater discrepancy, his Quick value being 36 per cent with a proconvertin concentration of only 4 per cent. In all of these patients following injection of the extract the Quick values remained higher than the proconvertin concentration, particularly during the first hour when differences of 35 to 60 per cent were frequently noted. This increased discrepancy gradually diminished toward the end of the experiments and was always gone by the following day. A comparison of the results of these two tests in N. C. following injection of the extract is shown in Figure 5.

In the one patient with moderate congenital hypoproconvertinemia there was fairly good agreement between the results of the Quick and proconvertin tests both before and after all three injections of extract. Before injection the proconvertin varied between 26 and 35 per cent and the Quick value between 36 and 38 per cent. Following injection the Quick value was usually slightly greater than the proconvertin concentration but there were variations of as great as \pm 10 per cent.

In the normal subject receiving Warfarin two different situations were observed immediately following injection of the extract, depending upon the amount given. With the smaller dose, which elevated the proconvertin concentration to 54 per 


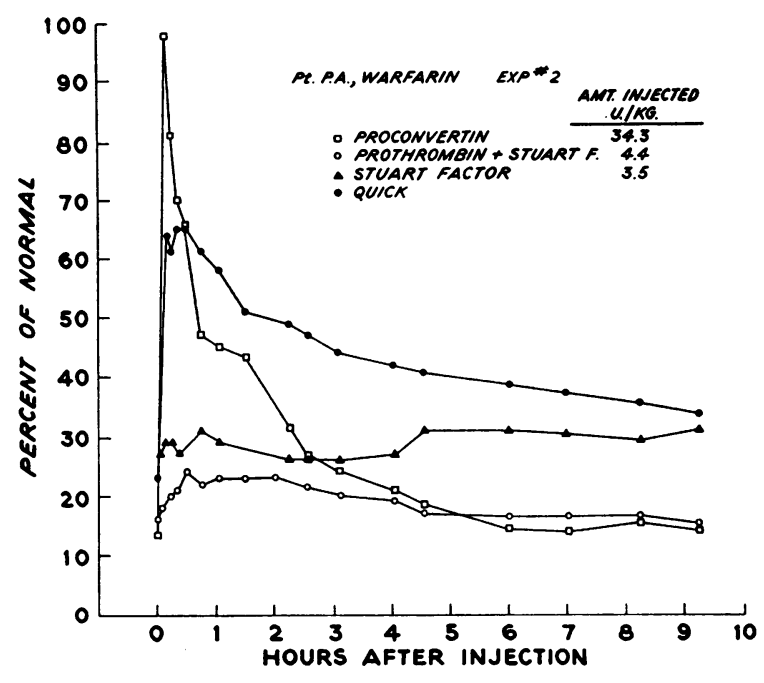

Fig. 7. THE EFFECT OF THE ADMINISTRATION OF A CONCENTRATED PROCONVERTIN EXTRACT (34.3 U PER KG) ON THE QUICK, PROCONVERTIN, PROTHRombin AND StUART FACTOR TESTS IN A NORMAL SUBJECT RECEIVING WARFARIN.

cent ten minutes after injection, the Quick value exceeded the proconvertin value by 9 per cent and remained 11 to 19 per cent higher throughout the period of the experiment (Figure 6). With the larger dose of extract, which elevated the proconvertin concentration to 96 per cent, the proconvertin value exceeded the Quick value by 35 per cent ten minutes after injection. At 30 minutes the results of the two tests were equal. Thereafter the Quick value exceeded the proconvertin result by as much as 29 per cent (Figure 7). These results show the strong influence which can be exerted on the Quick test by variations in the proconvertin concentration. Up to a certain point, despite a considerable deficiency in prothrombin and Stuart factor, elevation of the proconvertin concentration was capable of producing a similar elevation in the results of the Quick test. When the proconvertin concentration was raised to still higher levels, however, the Quick value did not increase proportionately. In this case the critical point was only slightly below the lower limit of normal for the Quick test. The effect of a normal proconvertin concentration in masking a deficiency of prothrombin or Stuart factor is apparent.

\section{DISCUSSION}

There was good agreement between the observed and predicted net increase in proconvertin concentration at $\mathrm{T}=0$ following the injection of extract in the severely deficient patients. The observed net increase, however, was consistently higher than that predicted in the normal and less severely deficient patients. This difference was not related to age, sex, body weight or the condition responsible for the proconvertin deficiency. It did not appear to be caused by the actual level of proconvertin measured in the patient's blood since in one severely deficient patient a total concentration of 167 per cent was achieved, while in several experiments on mildly and moderately deficient patients the highest concentration measured was below this level. Several different interpretations of these results are possible but none is convincing. Technical laboratory error seems unlikely because of the smoothness of the curves and the consistency of the finding. A systematic error in the method, resulting in values which were too low when proconvertin was measured in the extracts in vitro or too high when it was measured in the blood of the patient after administration of the extract in vivo, could account for the discrepancy.

In all experiments except that performed on the normal subject, disappearance curves having two exponential components were obtained. Both components of the curve had a faster rate in the more severely deficient patients, regardless of whether the cause of the deficiency was congenital or secondary to liver disease or the administration of Warfarin. It is not possible to determine from our data whether the first exponential represents endothelial adsorption, transfer of proconvertin into an extravascular compartment, a change in vitro in the degree of activation of proconvertin. the influence of a cofactor or inhibitor, or some other mechanism. The second exponential appears to measure metabolic destruction since it proceeds at a steady rate to an infinitely small value. Because the mechanism responsible for the first exponential of the disappearance curve is unknown, it is impossible to state why its rate is faster in the severe deficiencies. However, the data derived from the second exponential appear to indicate that the metabolic destruction rate of proconvertin is more rapid the more severe the deficiency. These results suggest that the reduced proconvertin concentration in these conditions may actually be caused by an increase in its rate of 
destruction as well as by a decreased rate of production.

The apparent disappearance rate of a substance is influenced by its rate both of production and destruction. We have made the fundamental assumption that all of the patients in this study were in a steady state at the time when our experiments were performed. We found no evidence that the rate of production of proconvertin is controlled by its concentration in the blood since there was no correlation between the total proconvertin concentration achieved and its apparent disappearance rate after injection of extract. If the production rate were controlled by the blood level, one would have expected the normal subject, whose proconvertin concentration was raised to 224 per cent, to have experienced a decrease in production rate and therefore to have shown the fastest apparent disappearance rate of the entire group, whereas, in fact, his was one of the slowest. Conversely, while the same subject was receiving Warfarin, a small dose of extract produced an elevation of his proconvertin concentration to a level of only 59 per cent, yet in this experiment the disappearance rate was faster than in any other experiment in the series. However, it is possible that Warfarin, liver disease, and the congenital deficiency state raise special considerations and that in the normal subject in the steady state the production rate of proconvertin is controlled by its level in the blood.

The site and mechanism of destruction of proconvertin are unknown. It does not seem probable that it is normally consumed in a process of continuous in vivo coagulation. If so, its rate of utilization should depend on the availability of other clotting factors. However, in the Warfarin experiments, prothrombin, Stuart factor, and probably PTC were markedly reduced, yet the disappearance rate of proconvertin was as rapid as in the severe congenital deficiencies in which these factors were present in normal concentrations. Furthermore, proconvertin is not required for the production of blood thromboplastin and is not destroyed in the process of blood clotting.

One hypothesis which might explain some of these results would involve the assumption that a part of the proconvertin in the body exists in an extravascular or endothelial compartment. In the severe deficiencies less proconvertin would be present in this compartment and it might, therefore, accept more proconvertin at a faster rate. Conversely, in the less deficient patients the compartment would be more nearly saturated and might be less capable of accepting additional proconvertin. The half-life of the first component of the disappearance curve would be shorter in the former instance than in the latter. The disappearance curve having a single exponential component in the normal subject might be explained on the assumption that the compartment was completely saturated, or at least had a higher concentration of proconvertin than that in the circulating blood.

The fact that the rates of both components of the disappearance curve show a direct relationship to each other suggests that the mechanism for the initial removal of injected proconvertin from the circulating blood may be the same as that for its ultimate destruction. A mechanism involving a greater degree of cellular or membrane permeability might account for the faster disappearance rate of both components of the curve in the severe deficiency states. An increased perfusion rate could result in more rapid delivery of proconvertin to a specific organ of destruction and also to tissues where it is not destroyed and can be fed back to the circulating blood. In this regard, it is of interest to note that Dicumarol significantly increases the initial transvascular transfer of T-1824-labeled plasma protein in the rabbit (16).

The differences between our results and those reported by Hitzig and Zollinger (7) in an infant with severe congenital hypoproconvertinemia are not great and could well be due to differences in the materials and techniques employed.

There are several reasons for the discrepancy between Frick's (8) results and ours in the normal subject receiving Warfarin. Following the administration of approximately $1,000 \mathrm{cc}$ of plasma in 30 minutes to four normal adult subjects, he reported a disappearance curve with a single exponential component having a half-time of 330 to 360 minutes. The net increase in clotting factor value was 18 to 35 per cent. We produced net increases in proconvertin of 46 and 95 per cent following the administration of concentrated extract within 5.5 minutes to one normal subject receiving Warfarin, and in both instances ob- 
tained disappearance curves having half-times of 12 and 13 minutes for the first exponential and 85 minutes for the second.

We have re-evaluated Frick's data and find that when the net increase in proconvertin over the baseline value (rather than total concentration) is plotted on semilog paper, the half-time shown by his data is 145 to 165 minutes rather than 330 to 360 minutes. Furthermore, the test he employed did not specifically measure proconvertin but rather a complex composed of proconvertin and Stuart factor. Since the half-time of Stuart factor appears to be longer than that of proconvertin, it is probable that the disappearance rate of the proconvertin was actually very close to that which we obtained. His failure to observe an initial more rapid component in the disappearance curve could have been due to the relatively long time required for the plasma infusion. Equilibrium could already have been established by the time his first observations were made 10 minutes after completion and 40 minutes after starting the plasma infusion.

In reporting a single experiment in a patient with cirrhosis of the liver, Didisheim and co-workers (9) stated that following injection of an extract containing approximately equal amounts of proconvertin and Stuart factor the half-time of proconvertin during equilibrium was 50 to 55 hours. Their data do not support this conclusion, since they also used a test which did not specificially measure proconvertin but rather the proconvertin, Stuart factor complex. Furthermore, at three hours after injection the result of this test had returned to its preinjection level. The further decrease in the test value over the subsequent four days could have been caused by the slower disappearance rate of Stuart factor contained in the extract given in the above experiment and on the previous day.

Because of the limitations of large plasma infusions it is difficult to compare their effects with those of concentrated extracts. Under the best of circumstances it is not possible to raise the proconvertin concentration in the recipient by more than 35 to 40 per cent with plasma infusions, and in interpreting the results one must consider the additional variable of changes in plasma volume. However, if allowances are made for these factors, Frick's results with plasma do not differ greatly from those we have obtained with concentrated extracts. Further studies with both substances will be required to determine whether the proconvertin in the extracts behaves in any way different from that in native plasma.

An opportunity for clinical trial of these extracts was provided by two patients with congenital hypoproconvertinemia. In one patient (M. M. no. 3) gingival bleeding of 24 hours' duration, following scaling of his teeth, immediately stopped after injection of $25 \mathrm{ml}$ of extract. On three occasions severe epistaxis of 12 to 24 hours' duration was promptly controlled in $\mathrm{Bi}$. C. by the intravenous administration of 15 to $30 \mathrm{ml}$ of extract. In each of the above episodes active bleeding was in progress at the time of injection and was observed to stop within five minutes after its completion. No further bleeding occurred and complete healing ensued. On another occasion $\mathrm{Bi}$. C. had frequent bloody stools of five days' duration, resulting in a decrease in his hemoglobin concentration to $4.2 \mathrm{~g}$. Following administration of 28 $\mathrm{ml}$ of extract, a single tarry stool occurred but no further gross bleeding was observed. The net increase in proconvertin at $T=0$ was 80 per cent. On all of the above occasions the amount of extract administered was sufficient to raise the patient's proconvertin concentration to or above the normal level. Although this effect was transient, the results suggest that if complete normality of the clotting mechanism can be achieved for even a short time it may be sufficient for normal hemostasis and healing to occur. However, since elevation of the Quick test value was of greater degree and longer duration than that of the proconvertin concentration, the possibility must be entertained that the therapeutic effects may have been due, at least in part, to some other unidentified prothrombin conversion accelerator contained in the extracts.

In all of the known blood clotting factor deficiency states except hypoproconvertinemia there is a defect in the intrinsic production of blood thromboplastin. In Stuart factor deficiency and hypoproaccelerinemia there is an additional failure of the extrinsic clotting mechanism which requires tissue thromboplastin for its proper functioning. It is only in hypoproconvertinemia that the coagulation defect is strictly confined to the extrinsic mechanism. It is therefore possible that 
the cessation of bleeding following the use of extracts which produce such transient restoration to normality may be uniquely associated with proconvertin deficiency states. Similar trials with large doses of concentrated extracts of other clotting factors in the appropriate deficiency states will be required to clarify this point.

\section{SUM MARY}

Extracts containing 35 to 88 times the proconvertin concentration of normal human plasma were produced by aluminum hydroxide adsorption of citrated plasma, elution with phosphate buffer, and precipitation of the protein in the eluate at $\mathrm{pH} 5.6$ with 40 per cent ethanol at $-5^{\circ}$ C. Following 16 injections of these extracts into nine human subjects, net increases in proconvertin of from 46 to 160 per cent were achieved. In one normal subject a disappearance curve with a single exponential component having a half-time of 230 minutes was found. In two mildly deficient and one moderately deficient congenital hypoproconvertinemic patients disappearance curves with two exponential components were found. The half-time of the first component was 18 to $30 \mathrm{~min}$ utes and that of the second was 210 to $240 \mathrm{~min}$ utes. In four severely deficient congenital hypoproconvertinemic patients, one patient with severe liver disease, and one normal subject receiving oral Warfarin, disappearance curves with two exponential components were found. The halftime of the first component was 11 to 17 minutes and that of the second 85 to 120 minutes.

The average net increase in proconvertin at $\mathrm{T}=0$ was 104 per cent of the predicted value in the severely deficient patients and 159 per cent in the normal and mildly and moderately deficient patients.

Intravenous administration of the extract on five occasions to two patients with congenital hypoproconvertinemia resulted in prompt cessation of gingival bleeding, epistaxis and rectal bleeding.

\section{REFERENCES}

1. Aggeler, P. M., Spaet, T. H., White, S. G., Fowell, A., and Johnson, F. Purification of plasma thromboplastin factor B. Rev Hémat. 1954, 9, 447.

2. Aggeler, P. M., Fowell, A. H., Johnson, F. F., Hoag, S., and Pool, J. G. Intravenous use of a con- centrated plasma P.T.C. preparation. Transactions of the Sixth International Congress, International Society of Hematology. New York, Grune \& Stratton, 1958, p. 490.

3. Hoag, M. S., Aggeler, P. M., and Fowell, A. H. Studies on the metabolism of proconvertin in congenital hypoproconvertinemia. Clin. Res. 1958, 6, 80.

4. Hougie, C., Barrow, E. M., and Graham, J. B. Stuart clotting defect. I. Segregation of an hereditary hemorrhagic state from the heteregenous group heretofore called "stable factor" (SPCA, proconvertin, Factor VII) deficiency. J. clin. Invest. 1957, 36, 485.

5. Aggeler, P. M. Plasma Thromboplastin Component Deficiency. Hemophilia and Hemophiloid Diseases, K. M. Brinkhous, Ed. Chapel Hill, Univ. of North Carolina Press, 1957, p. 111.

6. Alexander, B., Goldstein, R., Landwehr, G., and Cook, C. D. Congenital SPCA deficiency: A hitherto unrecognized coagulation defect with hemorrhage rectified by serum and serum fractions. J. clin. Invest. 1951, 30, 596.

7. Hitzig, W. H., and Zollinger, W. Kongenitaler Faktor-VII-Mangel; Familienuntersuchung und Physiologische Studien über den Faktor VII. Helv. paediat. Acta 1958, 13, 189.

8. Frick, P. G. Studies in the turnover rate of stable prothrombin conversion factor in man. Acta haemat. (Basel) 1958, 19, 20.

9. Didisheim, P., Loeb, J., Blatrix, C., and Soulier, J. P. Preparation of a human plasma fraction rich in prothrombin, proconvertin, Stuart factor, and PTC and a study of its activity and toxicity in rabbits and man. J. Lab. clin. Med. 1959, 53, 322.

10. Owren, P. A., and Aas, K. The control of Dicumarol therapy and the quantitative determination of prothrombin and proconvertin. Scand. J. clin. Lab. Invest. 1951, 3, 201.

11. Quick, A. J. The Physiology and Pathology of Hemostasis. Philadelphia, Lea \& Febiger, 1951, p. 125.

12. Hjort, P., Rapaport, S. I., and Owren, P. A. A simple, specific one-stage prothrombin assay using Russell's viper venom in cephalin suspension. J. Lab. clin. Med. 1955, 46, 89.

13. Bachmann, F., Duckert, F., and Koller, F. The Stuart-Prower factor assay and its clinical significance. Thromb. Diath. haem. 1958, 2, 24.

14. Sise, H. S., Lavelle, S. M., and Becker, R. A method for assay of Stuart factor. Proc. Soc. exp. Biol. (N. Y.) 1957, 96, 662.

15. Soloman, A. K. The kinetics of biological processes. Special problems connected with the use of tracers. Advanc. biol. med. Phys. 1953, 3, 65.

16. Nelson, T. E., Jr., Castrc ova, E., and Hyman, C. The effect of Dicumarol on the transvascular exchange of T-1824-labeled protein in rabbits. Circulat. Res. 1956, 4, 308. 